\title{
Studies on Biology of Predatory Bug, Nesidiocoris tenuis (Reuter) on Tuta absoluta (Meyrick)
}

\author{
E. T. Lakshmi Sireesha*, T. Ramesh Babu and S. R. Koteswara Rao \\ Department of Entomology, S.V. Agricultural College, ANGRAU, \\ Tirupati-517 502, A.P., India \\ *Corresponding author
}

A B S T R A C T

\section{Keywords}

N. tenuis, Total life period, biology,

T. absoluta

\section{Article Info}

Accepted:

10 July 2020

Available Online:

10 August 2020
Nesidiocoris tenuis (Reuter) (Hemiptera: Miridae) is an effective predator of pests of tomato crops and a promising biocontrol agent of Tuta absoluta (Meyrick) (Lepidoptera: Gelechiidae). The aim of this study was to know the biology of the predator, $N$. tenuis on $T$. absoluta. This study was revealed that egg period as 6.97 days and number of nymphal instars was five. The duration of I, II, III, IV and V instar nymphs was 2.71, 3.09, 2.83, 3.06 and 2.76 days, respectively and total nymphal period was 14.48 days. The longevity of adult was 7.43 days. The total life period was observed 28.89 days when fed on T. absoluta.

\section{Introduction}

Nesidiocoris tenuis (Reuter, 1895), belonging to the plant bug family Miridae (Hemiptera), is widely distributed in the Palaearctic and Mediterranean regions (Kerzhner and Josifov, 1999; Sanchez et al., 2008). This polyphagous mirid is commonly found on various plants in a variety of natural ecosystems (Alomar and Albajes, 1996; Perdikis and Lykouressis, 2004; Sanchez et al., 2004), and has a wide range of host plants, including some greenhouse crops (Sanchez et al., 2008). Some reports have classified this species as an insect pest, as it can damage crops by directly feeding on host plants such as tomato and pepper (Schuh and Slater, 1995; Yasunaga, 2000; Wheeler, 2001; Arno et al., 2009; Wheeler, 2000a). Conversely, in many countries, this species has recently been used as a biological control agent in agroecosystems, in order to control major greenhouses insect pests such as Bemisia tabaci (Gennadius), Trialeurodes vaporariorum (Westwood), Macrosiphum euphorbiae (Thomas), Frankliniella occidentalis (Pergande), moths like Spodoptera exigua (Hubner) and Tuta absoluta (Meyrick) as this species is zoophytophagous, with predatory-preference feeding habits (Wheeler, 2001; Sanchez et al., 2008; Wheeler, 2000b; Bueno and van 
Lenteren, 2012; Urbaneja et al., 2012; Lins Jr et al., 2014). In recent years, it is sought as important biological agent of $T$. absoluta in vegetable crops (Ettaib et al., 2016). Therefore, in this study duration of egg, all nymphal stages, total nymphal and life period was observed on T. absoluta.

\section{Materials and Methods}

\section{Mass multiplication of predatory bug, N. tenuis}

The tomato pinworm was used as a prey for $N$. tenuis throughout the study period. Mass multiplication of predator, $N$. tenuis was done on tomato plants infested with $T$. absoluta under laboratory conditions at $25 \pm 2^{\circ} \mathrm{C}$ and $75 \pm 2$ per cent $\mathrm{RH}$.

A laboratory population was established with field collected population of $N$. tenuis. This culture was maintained in plastic jars provided with $T$. absoluta infested tomato leaves as a source of food until the nymphs of $N$. tenuis becomes adults. These adults were transferred to oviposition cages for mating. Fresh tomato seedlings were provided daily for egg laying. Seedlings were inspected continuously for the emergence of nymphs. Later, nymphs were collected and reared in plastic jars provided with different stages of T. absoluta. The food was provided daily for developing nymphs of $N$. tenuis till they moult into adult. The adults were collected and released into oviposition cages for further culturing of $N$. tenuis. Rearing was continued and the culture was used to study the biology of $N$. tenuis.

\section{Biology of N. tenuis}

The initial population of $N$. tenuis was collected from the infested fields of tomato. The mass culturing of $N$. tenuis in rearing cages was done on tomato plants infested with tomato pinworm, T. absoluta under laboratory conditions. Developmental biology of $N$. tenuis was studied on the tomato leaves infested with $T$. absoluta at temperature $25 \pm$ $2^{0} \mathrm{C}$ and $75 \pm 2$ per cent RH. Tomato seedlings infested with $T$. absoluta raised in plastic pots were exposed to $N$. tenuis in rearing cages for oviposition inside the oviposition cage. After 24 hours, the seedlings were removed and kept for further development. Since the eggs of the bug were deeply embedded in the leaves or stems and could not be located, no observation was carried out during the egg stage. Seedlings were inspected daily and the nymphs emerged were collected and reared individually in petri plates by providing the different stages of $T$. absoluta as prey. Tomato leaves infested with tomato pinworm was provided as prey to each nymph in the individual rearing petri plates. The leaf petiole was wrapped with moist cotton to keep it turgid. The food was changed daily and the petri plates under observation were examined at 24 hours interval for moulting of the nymph till all nymphs developed into adults. The duration of egg, each nymphal instar, total nymphal duration and duration from egg to adult emergence were recorded (Gavkare and Sharma, 2014). Mean and SD were calculated for the obtained data to know the biology of the predatory bug.

\section{Results and Discussion}

Developmental biology of $N$. tenuis was studied on T. absoluta at constant temperature of $25 \pm 2^{\circ} \mathrm{C}$ and $\mathrm{RH}$ of $75 \pm 2$ per cent and the results are presented in Table 1 and Fig. 1.

\section{Biology of predatory bug, $N$. tenuis}

A brief description of individual developmental stage is illustrated here under. Because of its zoophytophagus, the tomato leaves were provided as an alternative food source for $N$. tenuis. The predatory bug, $N$. tenuis was reared on the $T$. absoluta and 
maintained the culture of predator during the experimental period.

\section{Egg period}

Eggs are laid into the plant mesophyll tissue and cannot be seen with the naked eye. Egg period ranged from 6-8 days with an average of 6.97 0.37 days (Table 1 and Fig. 1).

\section{Nymphal period (instarwise)}

The newly hatched nymphs were yellowish green turned to bright emerald green as they develop. Nymphs have dark eyes and cannot fly. They were found on the underside of leaves in the growing plants and moved quickly when disturbed. They blended very well with plant material and like to hide so can be difficult to see. The nymphs moulted four times during their development before undergoing adult stage. The first instar nymphal period lasts for 2 to 4 days with an average of $2.71 \pm 0.53$ days (Table 1 and Fig.1). The second instar nymphal period lasts for 2 to 4 days with an average of $3.09 \pm 0.36$ days (Table 1 and Fig. 1). The third instar nymphal period lasts for 2 to 4 days with an average of $2.83 \pm 0.29$ days (Table 1 and Fig. 1). The fourth instar nymphal period lasts for 3 to 4 days with an average of $3.06 \pm 0.43$ days (Table 1 and Fig. 1). The fifth instar nymphal period lasts for 2 to 4 days with an average of $2.76 \pm 0.27$ days (Table 1 and Fig. $1)$.

\section{Total nymphal period}

The total nymphal development period lasts for 12-17 days with an average of $14.48 \pm$ 0.94 days (Table 1 and Fig. 1). The results of present study are comparable with the findings of Dessouki et al., (1976) who reported that the nymphal period ranged from 16.50 to 22.79 days.

Table.1 Duration (in days) of developmental stages of predatory bug, $N$. tenuis on tomato pinworm, T. absoluta

\begin{tabular}{|c|c|c|}
\hline Stages of $\boldsymbol{N}$. tenuis & Range of duration (days) & Mean \pm (S.D)(days) \\
\hline Egg period & $6-8$ & $6.97 \pm 0.37$ \\
\hline I instar & $2-4$ & $2.71 \pm 0.53$ \\
\hline II instar & $2-4$ & $3.09 \pm 0.36$ \\
\hline III instar & $2-4$ & $2.83 \pm 0.29$ \\
\hline IV instar & $3-4$ & $3.06 \pm 0.43$ \\
\hline V instar & $2-4$ & $2.76 \pm 0.27$ \\
\hline Total nymphal period & $12-17$ & $14.48 \pm 0.94$ \\
\hline Adult longevity & $6-10$ & $7.43 \pm 1.11$ \\
\hline Total life period & $26-31$ & $28.89 \pm 1.03$ \\
\hline
\end{tabular}

Mean values presented in the table are average of four replications 
Fig.1 Duration (in days) of developmental period of N. tenuis on tomato pinworm, T. absoluta

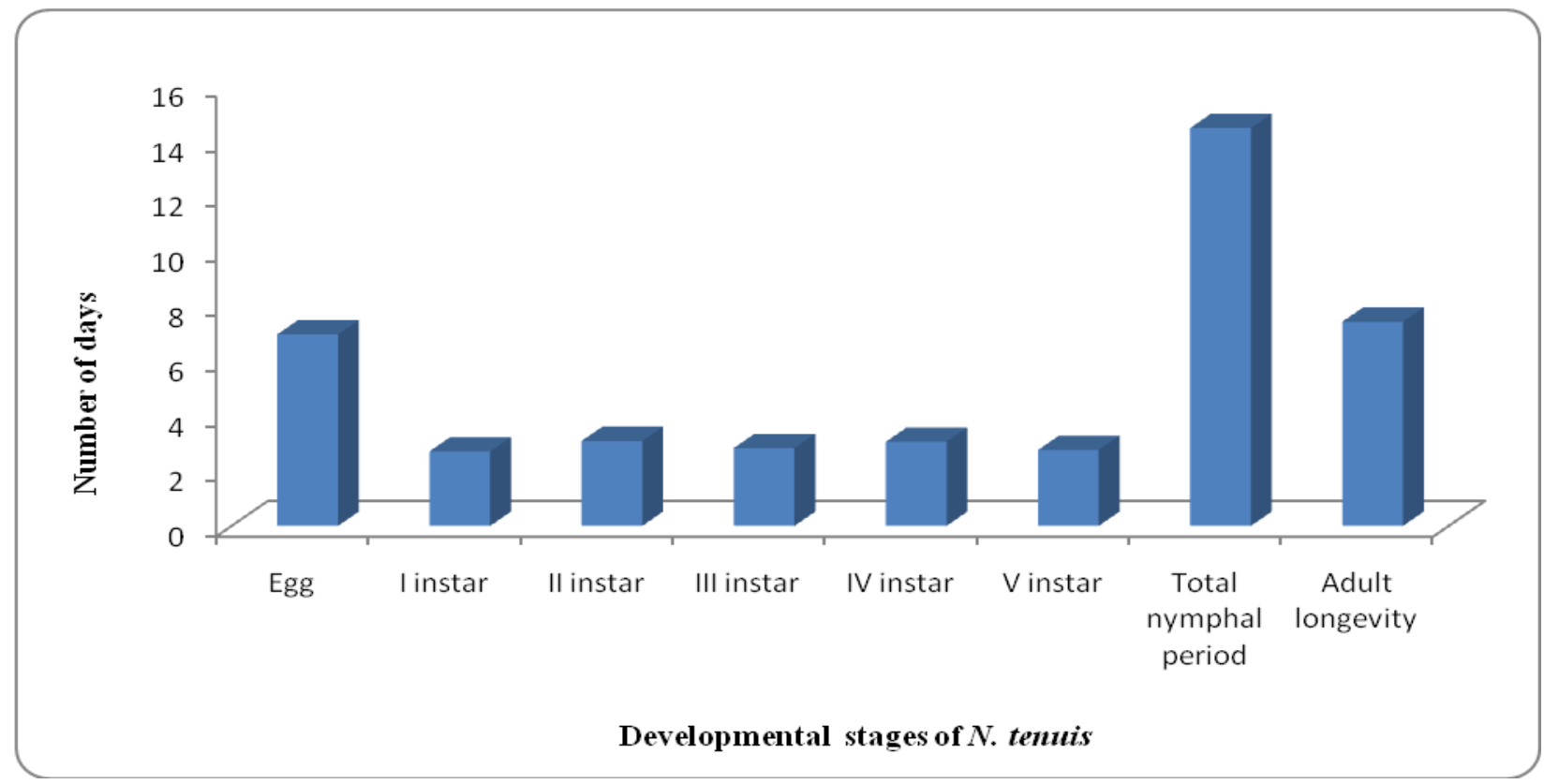

\section{Adult longevity}

Adults were bright green with black specks on their clear hind wings and large bulging dark eye. Adults have striped antenna and can fly. Longevity of adult was found to be 6 to 10 days with an average of $7.43 \pm 1.11$ (Table 1 and Fig. 1).

\section{Total life period}

The total life period (egg to adult longevity) was 26-31 days with an average of $28.89 \pm$ 1.03 days (Table 1 and Fig. 1).

\section{Acknowledgement}

I am indebted and grateful to Acharya N.G.Ranga Agricultural University, Guntur, Andhra Pradesh for providing financial support during my PG studies.

\section{References}

Alomar, O. and R. Albajes 1996 Greenhouse whitefly (Homoptera: Aleyrodidae) predation and tomato fruit injury by the zoophytophagous predator Dicyphus tamaninii (Heteroptera: Miridae). In Zoophytophagous Heteroptera: Implications for Life History and Integrated Pest Management", ed. by $\mathrm{O}$. Alomar and R. N. Wiedenmann, Entomological Society of America, Lanham, MD, pp. 154-177.

Arno, J., C. Castane, J. Riudavets and R. Gabarra 2009 Risk of damage to tomato crops by the generalist zoophytophagous predator Nesidiocoris tenuis (Reuter) (Hemiptera: Miridae). Bull. Entomol. Res., 100(1): 105-115.

Bueno, V. H. P. and J. C. van Lenteren 2012 Predatory bugs (Heteroptera). In "Insect bioecology and nutrition for integrated pest management", ed. by. A. R. Panizzi and J. R. P. Parra, CRC Press, Boca Raton, USA, pp. 539-569.

Dessouki, S. A., Kifl, A. H and Helal, H. A. 1976. Life cycle, hosts plants and symptoms of damage of the tomato bug, Nesidiocoris tenuis (Heteroptera: Miridae), in Egypt. Journal of Plant Diseases and Protection. 83: 204-220.

Ettaib, R., Belkadhi, M. S and Ben, B. 2016. 
Study of the biotic potential of indigenous predator Nesidiocoris tenuis on Tuta absoluta pest in geothermal culture in the south of Tunisia. Journal of Entomology and Zoology Studies. 4(6): 692-695.

Gavkare, O and Sharma, P.L. 2014. New record of Nesidiocoris tenuis (Reuter) (Hemiptera: Miridae) associated with Bemisia tabaci Gennadius (Hemiptera: Aleyrodidae) on tomato from Maharashtra, India. Journal of Biological Control 28(2): 53-54.

Kerzhner, I. M. and M. Josifov 1999 Cimicomorpha II. Miridae. Catalogue of the Heteroptera of the Palaearctic region. Vol. 3. Netherlands Entomological Society, Amsterdam, pp. 1-577.

Lins, Jr J. C., J. J. A. Loon, V. H. P. Bueno, D. Barbosa, M. Dicke and J. C. Lenteren 2014 Response of the zoophytophagous predators Macrolophus pygmaeus and Nesidiocoris tenuis to volatiles of uninfested plants and to plants infested by prey or conspecifics. Biocontrol, 59(6): 707-718.

Perdikis, D. C. and D. P. Lykouressis 2004 Macrolophus pygmaeus (Hemiptera: Miridae) population parameters and biological characteristics when feeding on eggplant and tomato without prey. $J$. Econ. Entomol., 97: 1291-1298.

Reuter, O. M. 1895 Ad cognitionem Capsidarum. III. Capsidae ex Africa boreali. Revue d'Entomologie. Caen, 14: 131-142.

Schuh, R. T., and J. A. Slater 1995 True bugs of the world (Hemiptera: Heteroptera): Classification and Natural History. Cornell University Press, Ithaca and
London, pp. 1-336.

Sanchez, J. A. D. Gillespie and R. McGregor 2004 Plant preference in relation to life history traits in the zoophytophagous predator Dicyphus hesperus. Entomol. Exp. Appl., 112: 7-19.

Sanchez, J. A., A. Lacasa, J. Arno, C. Castane and O. Alomar 2008 Life history parameters for Nesidiocoris tenuis (Reuter) (Het., Miridae) under different temperature regimes. J. Appl. Entomol., 133(2): 125-132.

Urbaneja, A., J. G. Cabrera, J. Arno and R. Gabarra 2012. Prospects for the biological control of Tuta absoluta in tomatoes of the Mediterranean basin. Pest Manag. Sci., 68(9): 1215-1222.

Wheeler, A. G. Jr. 2000a Plant bugs (Miridae) as plant pests. In "Heteroptera of Economic importance", ed. by C. W. Schaefer and A. R. Panizzi, CRC Press, Boca Raton, Florida, pp. 37-83.

Wheeler, A. G. Jr. 2000b Predacious plant bugs (Miridae). In "Heteroptera of Economic importance", ed. by C. W. Schaefer and A. R. Panizzi, CRC Press, Orlando, Florida, pp. 657-693.

Wheeler, A. G. Jr. 2001 Biology of the Plant Bugs (Hemiptera: Miridae): pests, predators, opportunists. Cornell University Press, Ithaca, New York, pp. 1-507.

Yasunaga, T. 2000 An annotated list and descriptions of new taxa of the plant bug subfamily Bryocorinae in Japan (Heteroptera: Miridae). Biogeography, 2: 93-102.

\section{How to cite this article:}

Lakshmi Sireesha, E. T., T. Ramesh Babu and Koteswara Rao K. 2020. Studies on Biology of Predatory Bug, Nesidiocoris tenuis (Reuter) on Tuta absoluta (Meyrick). Int.J.Curr.Microbiol.App.Sci. 9(08): 97-101. doi: https://doi.org/10.20546/ijcmas.2020.908.010 